\title{
Membaca, Mengamati, Mendiskusikan, dan Menulis: Tradisi Akademik di Pasca Sarjana
}

\author{
Ismail Suardi Wekke \\ Pascasarjana Sekolah Tinggi Agama Islam Negeri (STAIN) Sorong \\ Email: iswekke@gmail.com
}

\begin{abstract}
ABSTRAK
Pendidikan pascasarjana menjadi kesempatan untuk mendudukkan kajian dalam diskursus yang lebih luas pada konteks keilmuan. Kertas kerja ini menjadi panduan bagi mahasiswa di pascasarjan Sekolah Tinggi Agama Islam Negeri Sorong dalam aktivitas pembelajaran selama satu semester. Termasuk dalam narasi kertas kerja ini, kemampuan yang perlu dilatihkan untuk mahasiswa pascasarjana.
\end{abstract}

Kata Kunci: pascasarjana; pendidikan tinggi; tradisi akademik.

\section{Pendahuluan}

Aktivitas belajar menjadi kesempatan untuk memeroleh pengalaman. Dengan pengalaman yang ada, sebuah peluang untuk menemukan sebuah andaian. Pengalaman belajar dilatihkan dalam kesempatan demi kesempatan sehingga akan membentuk keterampilan. Dalam kelas-kelas mahasiswa pascasarjana, dituntut untuk lebih independent. Mahasiswa idealnya memiliki inisiatif dan keinginan untuk belajar mandiri. Sehingga hasil yang diperoleh seusai masa studi akan mendapat nilai tambah dibandingkan ketika masuk pertama kali sebagai mahasiswa magister.

Pendidikan tinggi tidak dapat melepaskan diri dari aktivitas keagamaan (Hermawanto, Ashrori, \& Wekke, 2019). Maka, aktivitas pendidikan tinggi jug aterkait dengan tradisi keagamaan yang berlangsung di masyarakat. Sekaligus sebuah kesempatan untuk transformasi pendidikan yang pada akhirnya akan berujung pada pengembangan masyarakat dan juga membangun moderasi keberagamaan, jika itu dikaitkan dengan perguruan tinggi keagamaan Islam (Mujahidah, \& Wekke, 2019). Pascasarjana sendiri, perlu sebuah aksentuasi dan akselerasi sehingga dapat menjadi bagian dalam berkontribusi bagi kemajuan ilmu pengetahuan (Wekke, 2019). Pascasarjana tidak lagi semata pada aktivitas pembelajaran yang bertumpu pada aspek mengetahui dan memahami saja. Sekaligus, pascasarjana mengemban misi untuk integrasi antara agama dan sains dalam diskursus keilmuan (Abbas, \& Wekke, 2019). Walaupun di sisi lain, perguruan tinggi dipandang juga sebagai layanan konsumen (Wekke, Qadri, Saeka, \& Idris, 2018).

Kertas kerja ini merupakan panduan perkuliahan sebagai overview mahasiswa pascasarjana dalam menyelesaikan perkuliahan. Sebagai penutup perkuliahan, ini akan menjadi tambahan maklumat atas proses dan juga bahan-bahan yang sudah disajikan selama ini. 


\section{Bentuk Latihan}

Untuk memperkaya pengalaman belajar, maka untuk mata kuliah ini dilakukan dalam tiga bentuk yaitu:

Pertama, merevisi book review. Memperkaya bacaan. Dari buku pilihan yang sudah dibahas sebelumnya, silahkan diperkaya dengan menuliskan sub-judul konstruksi teoritis dari artikel yang sudah ada. Secara teknis menemukan kekayaan literatur dalam fase awal dapat dilakukan dengan pencarian menggunakan Google Scholar. Selanjutnya, dapat juga menggunakan Research Gate untuk menemukan artikel yang relevan. Walau tidak dengan kata kunci yang sama, Research Gate akan menampilkan artikel-artikel yang relevan jika mengakses sebuah artikel yang sudah tersedia di Research Gate.

Kedua, merevisi artikel, baik artikel kelompok maupun artikel individual. Wawasan artikel yang diperluas, tidak lagi terbatas pada wawasan lokal ataupun regional. Penelusuran literatur yang memadai (jika perlu mengetikkan angka, maka paling tidak, jangan sampai kurang dari 15 artikel).

Terakhir, bab dalam buku. Ruang yang tersedia lebih luas berbanding dengan space yang ada untuk artikel jurnal. sehingga latihan ini dapat ditulis dengan narasi yang lebih luas.

Dengan demikian, setiap mahasiswa perlu menyelesaikan empat paper. Ini dengan mengacu kepada struktur dan format penulisan artikel jurnal. bukan sekadar makalah saja. Proses yang dilalui merupakan seri keterampilan dengan mengidentifikasi ide sampai pada proses publikasi (Farid, \& Wekke, 2019). Kemampuan yang diperlukan dari semua itu adalah menyintesis literatur-literatur yang ada untuk disajikan kembali dalam bentuk kondisi yang mutakhir (Rahayu, Syafril, \& Wekke, 2019).

\section{Kriteria Penulisan}

Dalam proses menulis, mahasiswa perlu memperhatikan tiga hal yaitu 1) Lihat kesesuaian dengan mata kuliah. Jangan sampai topik yang ditulis tidak terkait secara langsung dengan mata kuliah. 2) RPS (Rancangan Pembelajaran Semester) menjadi contoh topik-topik yang dapat dituliskan, dan 3) Menarik, dalam arti aktual dan faktual. Dalam kelas yang sama di tahun sebelumnya ada topik tentang "Kepemimpinan Menteri Agama dalam Pemberdayaan Kepala KUA di Maybrat”. Secara khusus, artikel ini sangat menarik dan aktual, tetapi tidak faktual. Sebab keterlibatan secara Menteri Agama dalam KUA melalui rentang kendali kepemimpinan yang relatif panjang. Kriteria nomor tiga perlu diperhatikan sehingga tidak menuliskan sebuah gagasan yang sekedar opini semata. 
Semua latihan perlu disampaikan dengan batas akhir pengumpulan tanggal 1 September 2019. Setelahnya, masih terbuka untuk dilakukan revisi. Sekaligus sebagai koreksi untuk memberi kesempatan mahasiswa melihat latihan sebagai sebuah proses yang tidak dapat selesai dalam satu kesempatan saja. Sehingga perlu proses perbaikan, baik melalui kelas maupun melalui blended learning. Bisa menggunakan pula korespondensi melalui email. Tidak harus melalui kelas saja. Media

\section{Kemampuan Mahasiswa Magister}

Latihan yang dilaksanakan dalam perkuliahan ini akan menjadi tahapan belajar. Dengan demikian, pengalaman belajar di semester ini akan diperkukuh pada semester-semester berikutnya.

Kemampuan mahasiswa pascasarjana, bukan saja dalam aspek mengetahui dan memahami, tetapi perlu perlu tingkatan yang lebih tinggi analisis. Mengacu kepada Taksonomi Bloom (1956), mahasiswa perlu mengidentifikasi kemampuan kognitif yang perlu dikuasai paling minimal. Kemampuan mengetahui dan memahami sudah dilatihkan dan sudah menjadi capaian pada peringkat sarjana. Ini juga diperkuat dan tetap menjadi dasar untuk memulai diskurus keilmuan.

Secara terprogram, berikut ini kemampuan yang perlu dilatihan 1) mengidentifikasi topik perkuliahan dalam bentuk penulisan review buku; 2) mengidentifikasi masalah dengan mengajukan topik permasalahan; 3) mengidentifikasi faktual dengan pengamatan; 4) menganalisis konteks keilmuan dengan menganalisis publikasi sebelumnya; 5) menulis artikel secara berkelompok dan mandiri; 6) menyunting artikel secara berkelompok dan mandiri; 7) memperbaiki artikel sesuai saran rekan sebaya dan dosen.

\section{Implikasi Teoritis}

Program magister bukan saja kelanjutan dari apa yang diselesaikan di tingkat sarjana. Walaupun dalam percakapan, alumni magister dan doktor juga dimasukkan dalam sebutan sarjana sebagai sebuah jenjang. Namun kesarjanaan (scholarship), menjadi sebuah sikap yang perlu diemban bagi yang bergelut dalam ilmu pengetahuan. Tantang pendidikan magister didalamnya mengintegrasikan soul. Jangan sampai wujud kecemerlangan akademik tetapi tidak ada soul yang mengiringi seluruh perjalanan itu (Lewis, 2006; Palfreyman, 2010; Tull, 2007). Maka, menjadi mahasiswa pascasarjana perlu menemukan passion masing-masing.

Minhaji (2013) mengemukakan bahwa mahasiswa pascasarjana menggeluti tradisi membaca, mengamati, dan menulis. Satu hal lagi yang perlu ditambahkan sebagai aktivitas yang 
mengikat ketiganya sebagai perantara yaitu diskusi. Dengan kesempatan untuk diskusi bisajadi ini akan menjadi dua peluang, traingulasi, dan menemukan insight lain dari rekan diskusi. Dengan tambahan data atau juga referensi dari rekan diskusi akan menjadi mempertingkatkan kualitas artikel. Ini merupakan review awal yang didapatkan dari rekan sebaya.

Dengan adanya teknologi bukan berarti bahwa tradisi akademik akan hilang begitu saja (Fraley, \& Vargas, 1975). Dengan teknologi, justru membantu mengakselerasi keberadaan dunia akademik. Dengan teknologi bisa lebih akurat. Sebagaimana Harvard (Bobbitt, 1946) dengan tradisi akademik yang melintasi ratusan tahun. Sebuah perjalanan yang dikukuhkan dengan tetap melintasi zaman dan juga perkembangan teknologi terkini. Justru dengan adanya teknologi, menjadikan tradisi akademik dikemas dengan mengintegrasikan keperluan aktivitas dengan keberadaan teknologi itu sendiri.

Terakhir, pascasarjana menjadi bagian dalam pengembangan kajian Islam Indonesia. Dengan ini, maka pascasarjana perlu melakukan lompatan-lompatan dengan bantuan teknologi sehingga bisa membangun kajian Islam secara luas (Wekke, 2018). Dalam konteks Papua, perlu ditemukan inovasi dan prakarsa sehingga dapat bersanding dengan pendidikan nasional dan regional secara luas (Wekke, Kahar, \& Amri, 2018).

\section{Penutup}

Duduk di bangku pascasarjana merupakan kesempatan untuk melatihkan kemampuan dalam kaitan dengan pembentukan kesarjanaan. Ini merupakan fase dimana sebagai sarjana yang sudah memasuki tahap kesarjanaan yang ditandai dengan kewujudan sumbangsih keilmuan.

\section{Daftar Pustaka}

Abbas, T., \& Wekke, I. S. (2019). Yang Datang Setelah Hujan: Sains-Agama Penerang Kegelapan. https://doi.org/10.31227/osf.io/nfx4v.

Bloom, B. S. (1956). Taxonomy of educational objectives. Vol. 1: Cognitive domain. New York: McKay, 20-24.

Bobbitt, F. (1946). Harvard reaffirms the academic tradition. The School Review, 54(6), 326-333.

Farid, M., \& Wekke, I. S. (2019). Proses Menulis Artikel Ilmiah: Dari Ide Hingga Publikasi. https://doi.org/10.31227/osf.io/yhpvm.

Fraley, L. E., \& Vargas, E. A. (1975). Academic tradition and instructional technology. The Journal of Higher Education, 46(1), 1-15.

Hermawanto, A., Ashrori, M., \& Wekke, I. S. (2019). Tradisi Keislaman di Perguruan Tinggi. https://doi.org/10.31227/osf.io/29hba.

Lewis, H. R. (2006). Excellence without a soul: How a great university forgot education (pp. 1995-2003). New York: PublicAffairs.

Minhaji, A. (2013). Tradisi akademik di perguruan tinggi. Yogyakarta: Suka-Press.

Mujahidah, M., \& Wekke, I. S. (2019). Transformasi Perguruan Tinggi Keagamaan Islam Indonesia. https://doi.org/10.31227/osf.io/46evm.

Palfreyman, D. (2010). Excellence Without a Soul: How a Great University Forgot Education. 
Rahayu, T., Syafril, S., \& Wekke, I. S. (2019). Menyintesis Literatur Dalam Penulisan Artikel. https://doi.org/10.31227/osf.io/fxnha.

Tull, A. (2007). Excellence Without a Soul: How a Great University Forgot Education. Journal of College and Character, 8(4).

Wekke, I. S. (2018). Masa Depan Kajian Islam Di Indonesia. https://doi.org/10.31227/osf.io/36tua.

Wekke, I. S. (2019). Akselerasi Pembelajaran Pascasarjana Dalam Pengembangan Tradisi Keilmuan. https://doi.org/10.31227/osf.io/fw5r6.

Wekke, I. S., Kahar, M. S., \& Amri, I. (2018). Perguruan Tinggi Tanah Papua dan Strategi Pengembangan Pendidikan Tinggi. https://doi.org/10.31227/osf.io/m3kvb.

Wekke, I. S., Qadri, M. N., Saeka, S., \& Idris, I. (2018). Kualitas Sistem Informasi Akademik Dalam Meningkatkan Kepuasan Pelanggan di Perguruan Tinggi. https://doi.org/10.31227/osf.io/tdyu2. 